\author{
BOGDAN NOGALSKI \\ PRZEMYSŁAW NIEWIADOMSKI \\ AGNIESZKA SZPITTER
}

\title{
Dynamic competences in the opinion of the machine sector experts - from management theory to practice
}

Professor Bogdan Nogalski, honorary doctorate

WSB University in Gdańsk, Faculty of Finance and Management Institute of Management and Finance

Przemysław Niewiadomski, Associate Professor, Eng.

University of Zielona Góra,

Faculty of Economics and Management

Agnieszka Szpitter, Associate

Professor

University of Gdańsk, Faculty of Management, Institute of Organization and Management

\section{Introduction}

Business operations change with the growing complication of the conditions of operation (Trocki, Grucza, Ogonek 2009, p. 11$)^{2}$. Existence and development of the organization are inseparably related to the need of introducing changes concerning different aspects of its functioning (Skalik 2017, p. 125). Their introduction is a result of the imperative of maintaining balance with the environment. According to B. Nogalski and S. Klisza (2012, p. 15) adaptation to the environment is a basic prerequisite of the company's success. In connection with the above, the management sciences

1 The article refers to enterprises involved in the manufacturing of parts, subassemblies and ready-made farm machines; they are subjects of the research conducted so far by the authors. The article was created as part of the implementation of a scientific project financed by the National Science Center (NCN) under Decision No. DEC 2013/11/B/HS4/00697 entitled The strategic dimension of the dynamic capabilities of Polish enterprises, led by prof. K. Krzakiewicz from the Poznań University of Economics.

2 Changes concerning dynamics of the organization's environment and the nature of events occurring in it as well as the degree of complexity of the related problems are indicated by in his work by J. Skalik (2012, p. 30). 
literature devotes much attention to strategic adjustment. It has the external dimension and means adjustment of the possibilities of operations of the organization, its competences to the needs and requirements of the environment (Niewiadomski 2016, p. 38).

There is quite a common belief that the key and primary condition for efficient company management are competences (see: Bieniok 2016, p. 94). The relation of a business with the environment can be looked at through the prism of the concept of strategic adjustment (Nogalski, Szpitter 2012, p. 113), according to which managers make choices between revitalization processes, relying on the use of the previous competences, or adaptation processes, focused on remodelling core competences (Cyfert 2012, p. 124).

Since many researchers and managers have been still thinking about the essence, creation mechanisms and boundaries of dynamic competences (i.e. about the manifestation of the dynamic capabilities the enterprise has), at this point the authors formulate questions - related to this problem. How is the notion of dynamic competences understood by representatives of manufacturing companies from the agricultural machines sector operating in Poland? What dimensions should be considered when making the conceptualization of this notion? How to define a scale to valuate different ones of them?

It would seem that the notion of competences is clear and does not evoke discussion. However, literature provides a lot of different ways of interpreting competences. Methodological confusion has been created that sometimes leads to contradictory opinions, or even disputes, concerning what competences are indeed, and therefore - what methods to use to examine, and then improve them. In the context of the above, also interpretation of the notion dynamic competences involves many ambiguities. Dynamic competences are as difficult to define as to accurately differentiate in businesses' development processes. This notion is differently understood; for instance, in the strategic management theory there is a synonymous term of dynamic capabilities (Eisenhardt, Martin 2000; Karpacz 2014; Krzakiewicz, Cyfert 2016(1); Ortega 2010; Teece 2007; Teece 2012; Teece, Pisano, Shuen 1997).

The above questions, as well as the conviction about the presence of business demand for applicable results, were the main inspirations to undertake research $^{3}$. The main purpose of the thesis is thus an attempted answer to the

3 The study is an answer to the appeal of J. Stankiewicz, P. Eychmus and H. Bortnowska (2011, $p$.582) according to whom it is necessary to apply theory to practice and deliver management instruments to managers. The above is confirmed by B. Nogalski, A. Szpitter and P. Niewiadomski

Dynamic competences in the opinion of the machine sector experts - from management theory to practice 
question: how is the notion 'dynamic competences' understood by representatives of manufacturing companies operating in the Polish farm machines sector? In order to achieve the so specified goal, partial tasks had to be formulated and attained. In the theoretical and design layer, the literature reconstruction and interpretation method will be used, implying discussion in the group of carefully selected experts operating in the sector; as a result of creative discussion, key dimensions/ distinguishing marks of dynamic competences will be generated. In the further part such procedure will be reflected in the conceptualization of the notion 'dynamic competences', in particular bearing in mind that "definition brings clarity" (Falencikowski 2013, p. 19). Following this guideline, the definitionbased perspective of dynamic competences dimensions has been presented as formulated by numerous researchers and experts invited to the research.

The authors assume the form of a conversation in which the researcher has full initiative in the deliberations - of course following the purpose of the research. In the empirical perspective, it has been recognized as reasonably practical to determine the hierarchy of importance of dimensions of different dynamic competences. The task of carefully selected respondents will be to choose those of the suggested dimensions of dynamic competences that reflect most the sense of this notion.

It seems that complexity of the problems and, so far, little scientific recognition justify treatment of the mentioned problem areas as the subject matter of the research. Additional confirmation for the need to initiate research results also from the following facts:

- on the publishing market there are no studies concerning dynamic competences of industrial companies, especially in terms of their effect on flexibility implying the heterogeneous character of the product portfolio,

- the subject literature usually refers to general expressions in this respect; absence of studies can be noticed, presenting specific definitions that can be translated into management practice.

According to the intention of the authors, the work is supposed to cast light on a wider perspective of defining dynamic competences in the context of

(2017, p. 225) writing: „In the present situation, organizations, due to continuous and fluctuating variability of the conditions, expect management sciences to offer adequate proposals and solutions in the globally transforming reality". however, this does not mean departure from theory explaining the examined phenomena (Czakon, 2017, p .143). Nonetheless, attention is paid to the fact that the pursuit of theory should not be exaggerated, as in the case of a vast majority of articles the authors of which have the aspiration to attain the theory-forming goal (Hambrick, 2007, 1364 and the following). 
flexible organizations. The presented research results have determined the direction of the authors' further works that will soon be presented in separate publications.

\section{Competences and dynamic capabilities-problems related to conceptualization}

The notion synonymous with competences are capabilities. It is not a rare situation that the notions capabilities and dynamic competences are regarded as synonyms. Originally, distinguishing the notion 'competences', it should be emphasized that capabilities are usually gained before commencing the production activities, although they can be acquired and improved during subsequent implementations. In this perspective, capabilities are closer to skills and are an inherent component of dynamic competences. Capability is part of distinctive competences of a business confirmed by practice and experience.

Among numerous attempts to distinguish competences from capabilities, there are some that suggest superiority of competences over capabilities. In the paper competences have been separated from capabilities, indicating the clear differences between them. For instance, competences may be considered in comparison to the achieved results, while capabilities are identified with possibilities or skills. Capabilities will be treated as potential competences that are usually obtained before undertaking a given implementation and are independent from it; they can be held in a completely different area than the production being implemented, e.g. the ability to unify technology. In the case of competences, the situation is opposite, as they are disclosed while performing certain manufacturing operations.

However, more and more popular is the tendency, being, as stated by the authors, to a certain extent an expression of fashion, not only to expand the meaning of the term ' dynamic capabilities', but also to substitute the term 'dynamic competences' for it. As the authors predict, this is presumably an irreversible change. This is proven, for example, by the fact that the subject matter of dynamic capabilities - constituting the source of competitive advantages of enterprises - is discussed on the event organized on the annual basis by the Team of Professor K. Krzakiewicz - the conference entitled "Strategic dimension of dynamic capabilities of Polish companies". On the other hand, there is no scientific examination with regard to the essence and the scope of enterprises' dynamic competences.

The notion 'dynamic capabilities' owes its popularity to the search for new solutions to tackle the challenges that are faced by businesses in connection with

Dynamic competences in the opinion of the machine sector experts - from management theory to practice 
growing global competition, or treatment of knowledge and information as the potential that enables more effective competition on the market. The result of searches was to create a management concept based on capabilities.

Regardless of the foregoing - in the opinion of the paper authors - competences are disclosed in activities that are a sequence of certain capabilities. In view of the foregoing, they are of dynamic nature. In addition, the authors call into question the fact whether identification of competences with skills is good for an organization operating in the present economic reality, an organization which runs out into the future, gains new knowledge, stimulates intellectual curiosity as well as encourages discussion.

According to the authors of the paper, the main reason for the described classification discrepancies is different perception of the term dynamic competences'. In view of the foregoing, adoption of - an appropriate, depending on the needs - definition undoubtedly implies adoption of consistent criteria for components distinguishing competences as compared to dynamic capabilities. In conclusion, the terminological context of the notion competences as compared to capabilities is fuzzy. It may be stated that capabilities are not sufficient for one to be competent. Dynamic competences let the business fulfil expectations of achieving specific results. Businesses are capable of using their knowledge, skills and dispositions of employees, to achieve the goal. Competent is a company that, as a result of a proper attitude and characteristics, will be able to positively use their knowledge and capabilities. In view of the foregoing, it can be assumed that the level of competences is dependent on available knowledge, consisting of experience, current information and their context, capabilities and the ability of using them, and finally the attitude itself, motivation, behaviours and values.

Dynamic competences are distinguished by the ability to re-allocate production resources so as to produce goods effectively, ensuring acceptable quality. In the short term this means the ability to adapt to the changing conditions with the use of the existing resources. In the long term this is the ability to introduce new products, new resources and production methods and their integration with the existing production systems. Key here is the ability of the production system to change or react, while incurring small outlays from the point of view of time, cost or results of operations.

In the context of the above, the fact worth paying attention is that competences, like dynamic capabilities, are distinguishing marks that should characterize every company operating in the new conditions of the business environment and seeking to survive in it. As the ability to strategically respond to new criteria of the business environment in practice, this means use of methods, production 
and organizational processes, practices and tools, the majority of which has been developed so far (Sajdak 2014, p. 114 and the following).

Due to a continuous and fluctuating variability of the conditions, businesses must develop new features, behaviors and attitudes, which will constitute an adequate and effective response to the globally transforming reality (Nogalski, Szpitter, 2014, pp. 197-210). This means that a significant feature of the present times is recognition of competences and dynamic capabilities as a critical factor, decisive for survival or organizational development, and competent management of the attribute being dynamic competences becomes (in the conditions of uncertainty and dynamic changes) an instrument opening new horizons for the company.

To sum up the discussion concerning competences and capabilities, it is important that, when referring to different authors, while transmitting and comparing experience of various researchers, attention should be paid to the interpretation of this term by the given author. From the analytic point of view, it is important that the adopted definition should serve well the research goals, which is more elaborated later in the paper.

\section{Dynamic competences in management practice - creative discussion}

\subsection{Area and subject matter of research}

The study mentioned in this part of the paper was conducted on 11 May 2017 in the seat of the company Fortschritt, in Września - a manufacturer of parts, subassemblies and ready farm machines. In the first stage of the research - being preparatory study - the authors used the literature reconstruction and creative conversation method. 9 persons directly connected with companies producing components and parts for farm machines were invited to the negotiations, of which: 7 persons represented the medium companies, 2 persons represented small businesses (6 persons are owners of manufacturing companies from the examined sector; 2 persons are managers employed under contracts of employment, while 1 person is a proxy acting on behalf of the company he represents). While selecting consultants, account was taken first of all of their knowledge and practical professional experience. In each case these were professionally active persons, actively participating in management processes in the companies which they come from or which they work for.

The preparatory study conditioned conduct of the proper study; the main intention of the authors was to determine dimensions that would reflect best

Dynamic competences in the opinion of the machine sector experts

- from management theory to practice 
the sense of the notion 'dynamic competences'. The purpose of the discussion was only to properly select them without ranking them. The point was to create a set, from which - in the further part the research - it will be possible to choose the definitions most corresponding to the problem formulated in the study. The list was built so that it would be possible to modify and supplement it as required; it was assumed that the indicated distinguishing marks are not fixed categories.

The authors are aware that the conceptualization of dynamic competences is very difficult. As a matter of fact, particular researchers create a wide list of dimensions characterizing competences, naming and interpreting them differently. In addition, their selection is always a matter of convention; often depends on the company's or researcher's own demands, for which it is created.

The conversation conducted for the purposes of the present paper was prepared according to the scenario implied by the needs of the research. The form of dialogue was adopted, in which the researcher had full initiative in the deliberations; of course, following the purpose of the research. With regard to the presented assumptions and literature concepts as well as on the basis of experience from their companies, the task of the experts was to present their views in the discussed extent. Since, in the opinion of the authors, research based on a high number of variables would strongly complicate its implementation - preventing formulation of important conclusions - it was important to determine a short list of definitions - implied by the observations of management practitioners.

\subsection{Distinguishing marks of dynamic competences - preparatory study (modelling)}

It was important - from the point of view of the conducted research - to present selected definitions, compare them with each other as well as confront them with the experts' opinions. As a result of the conversation - on the basis of the list prepared by the authors - 26 distinguishing marks of dynamic competences were generated. After the finished session, the authors grouped together - according to the interlocutors' suggestions - similar ideas, which made it possible to prepare the final list of 23 components.

The list of generated dimensions/distinguishing marks of dynamic competences was as follows:

D - [1] Ability to learn fast, adapting the company to changes simultaneously implementing different action options; 
D - [2] Creativity of employees; thinking leading to original and appropriate solutions; ability to create something new;

D - [3] Knowledge in the field of technology, design, operation and construction of machines;

D - [4] Having resources implying the ability of the company to provoke and take advantage of opportunities;

D - [5] Ability to dynamically adjust the goals of the organization to the conditions in which it has to operate;

D - [6] Resources being in readiness for intensive development - through the implementation of appropriately designed and adjusted - according to the goals adopted by the organization;

D - [7] Knowledge, ability, experience and motivations to carry out evolutionary and revolutionary changes;

D - [8] Possession of and the ability to use resources in the form of machines, tools and devices used for processing and manufacturing;

D - [9] Attitudes and behaviours of performers of the tasks, which will cause acceptance for new technologies, which, in the perspective of having dynamic capabilities, with their appropriate reconfiguration, implies maintenance of the leading cost leader's position;

D-[10] Ability to practically apply knowledge determining the ability to immediately respond, which, through properly harmonized resources reconfiguration, implies the possibility of taking advantage of opportunities appearing in environment;

D - [11] Collections of knowledge and skills underlying the enterprise's sustainable competitive advantage. To a large extent they are of intellectual nature and are related to management systems. They apply to the entire enterprise; are interfunctional (Quinn, Hilmer, 1996, pp. 63-73); in order to maintain competences, they need to be anchored in the organizational culture as well as implanted into the organizational structure and systems of actions (Bratnicki, 2000, p. 25);

D - [12] Ability to adapt to changes taking place within the enterprise and in its environment;

D - [13] Visible characteristics, in the form of material resources, knowledge, skills or behaviours, permitting successful utilization of any emerging opportunities;

D - [14] Knowledge, experience, capabilities and dispositions for team activities applied at the work post, specific skills required at work and personal culture; 
D - [15] Ability to solve technological and management (managerial) problems on the basis of knowledge and experience;

D - [16] Integrated utilization of capabilities, personality traits as well as acquired knowledge and skills, in order to achieve successful implementation;

D - [17] Instructions regarding know-how, skills and attitudes, making it possible to pursue production objectives at an appropriate level;

D - [18] Knowledge, manual capabilities (dispositions), experience (routine) and motivations of employees, which as a result of the adopted technical culture bring the company closer to implementation of the adopted assumptions;

D-[19] Art of effective, responsible, energetic, economic and competent management of the whole of matters, tangible, capital, human and information resources, intended to execute the assumed tasks;

D - [20] Tangible resources, including means of production (machines, devices, tools, instruments), items of work (raw materials, materials, semifinished products, energy) and technology (method of operation) that, as a result of available engineering knowledge and the skill of its translation into practical solutions, and also based on dispositions of executive employees, their experience, attitudes, motives and behaviours (intangible resources) allow the enterprise to take advantage of the opportunities emerging in the environment;

D - [21] Strategic capabilities of the enterprise offering the possibility to take actions that are difficult to imitate. They are to be developed in order to take advantage of new opportunities. Operations are indicated that are considered as unique resources in the company (Bratnicki 2000, p. 16).

D - [22] Key competencies being bundles of resources, processes and capabilities underlying the enterprise's competitive advantage, providing access to new target and supply markets. They affect reduced production costs that are difficult for competitors to imitate. They allow to create a network of internal and external bonds constituting the basis for creating value added (Thompson, Richardson 1996, pp. 5-19);

D - [23] The technological potential which, by knowledge, skills, motor characteristics of executive employees, their attitude and experience, contributes to achieving specified (desired) results.

The presented definitions are considered as a context of various approaches. The essence of dynamic competences presented by the given expert is relatively dispersed; some of the proposals are limited to reacting, others only to adaptation of the enterprise to the changing conditions, yet others limit the 
scope of competence solely to changes or available resources of the enterprise. The conducted research indicates identification of dynamic competences with ${ }^{4}$ :

- ability of the organization to intentionally create, expand or change its resource-based potential,

- process of integrating, reconfiguration, acquisition and release of resources in order to be able to respond to opportunities appearing in the environment, or even independently provoke their emergence,

- using them to manipulate the existing resources of the enterprise in order to create their new configurations.

The above, in the conducted studies, is also confirmed by K. Krzakiewicz and S. Cyfert (2016 (2), p. 87) noticing that competence of the organization incorporates a certain combination of resources, persons, organizational structures, knowledge, rules, etc., which allow the organization to do what other organizations are not capable of. Adoption of the assumption that technological and management competencies reflect both individual skills and experience as well as distinctive ways of action inside the company, allows one to draw a conclusion that the essence of the company consists in the ability to create, transform, gather, integrate and use knowledge as assets (Krzakiewicz, Cyfert 2016 (3), p. 51).

The conducted arguments also indicate a relationship between dynamic competences and situations conducive to achievement of the company's objectives by means of the resources it has or it may acquire (e.g. cooperation), especially that business improvement, to some extent, consists in searching, grasping and creating development opportunities. Situations conducive to achievement of goals are opportunities appearing in the environment or provoked by the company. Goal as the indicator in the field of opportunities is also stressed by S. Trzcieliński (2011, p. 49), according to whom an opportunity is a situation favorable to the entity in achievement of the intended goal or the desired effect which exists in the environment of this entity or is the requested state of characteristics of this environment. It is confirmed, among others, by the concepts of J.C. Collins, J.I. Porassa, K. Eisenhardt and D.N. Sulla (Nogalski, Niewiadomski, 2017 in print) supported by empirical research from which it can be concluded that opportunities are enterprises' important development impulses. Similar

4 The authors point out that with regard to the resources category, classical economics rather used the notion , production factors'. In connection with the above, in the adopted definition, the notion ,resources' is understood in the meaning of each production factor at the disposal of the enterprise, used in the production process.

Dynamic competences in the opinion of the machine sector experts - from management theory to practice 
conclusions are presented in his research results by K. Krzakiewicz (Guliński, Studziński 2008, p. 88). In more than half of the enterprises from among the examined ones, the dynamic approach is prevalent, focused on taking advantage of opportunities. It may be assumed that dynamic competences developed in reality by enterprises are indeed a one-of-the-kind combination of material and intangible resources focused on plan and opportunity. For the company, dynamic competences are a bundle of resources making an event or a series of events - created as a result of various circumstances - (e.g. establishment of a market niche) an opportunity to achieve additional benefits, including increase in the material and/or intangible value (Krupski 2005, p. 66).

\subsection{Dynamic competences - hierarchy of distinguishing marks}

Theoriginally preparedlist of 23 dynamic competencedimensionswassubjected to verification among 43 carefully selected representatives of manufacturing companies from the agricultural machines sector. Experts - because the authors regard the persons taking part in the study as such - represented the following enterprises: micro -3 persons $(6.98 \%)$, small -17 persons $(39.53 \%)$, medium 23 persons (53.49\%). In the opinion of the authors the enterprises subjected to the study, by their structure and management process - under the conditions of the emerging market opportunities - are able to activate their resources rapidly and smoothly to generate value for the customer. When making the decision to select experts, an important criterion was direct acquaintance of the expert with the researchers. It has made it possible to determine whether the person performing the assessment has sufficient knowledge with regard to the issues raised, supported by grounded practical experience in the industry. The purpose of the study was to verify the accuracy of selecting the particular components. The respondents were asked to indicate those distinguishing marks that, in their opinion, most accurately reflect the sense of the dynamic competences definition. Significance was marked on a 5-point scale, where 1 - small significance and 5 very high significance of a component.

As it results from the conducted research, dynamic competences are most accurately distinguished by tangible resources, including means of production (machines, devices, tools, instruments), items of work (raw materials, materials, semi-finished products, energy) and technology (method of operation) that, as a result of available engineering knowledge and the skill of its translation into practical solutions, and also based on dispositions of executive employees and their experience attitudes, motives and behaviours (intangible resources)

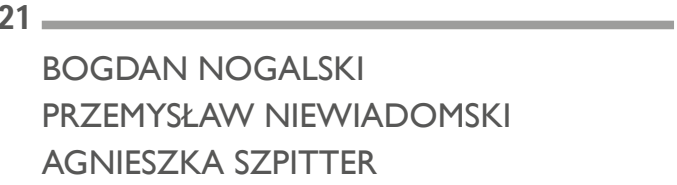


allow the enterprise to take advantage of the opportunities emerging in the environment (average evaluation 4.86; 38 (88.4\%) of the indications for 5 point score).

The respondents also pointed to the definition developed by Thompson and Richardson (1996, pp. 5-19) as significant - identifying dynamic competences with a bundle of resources, processes and capabilities implying a company's competitive advantage, providing access to new target and supply markets (average score $4.79 ; 37(86.0 \%)$ of the indications for 5 point score). According to the adopted definition, dynamic competences contribute to reduced production costs. These in turn are difficult for competitors to imitate. They allow to create a network of internal and external bonds constituting the basis for creating value added. Here significant is the technological potential which, by knowledge, skills, dispositions of executive employees, their attitude and experience, contributes to achieving specified (desired) results (average score 4.77; 35 (81.4\%) of the indications for 5 point score). The aspect of material resources in the form of machines and intangible resources, namely knowledge, skills and attitudes, which enable production objectives to be pursued at an appropriate level, is also stressed by another definition (average score 4.67; 32 (74.4\%) of the indications for 5 point score). According to the respondents, important from the point of view of the conceptualization of dynamic competences is the definition by M. Bratnicki (2000, p. 16), according to whom these are strategic capabilities of the enterprise offering the possibility to take actions that are difficult to imitate (average score $4.67 ; 32(74.4 \%)$ of the indications for 5 point score). According to the approach promoted by the author, competences of an enterprise are to be developed for the purpose of taking advantage of new opportunities. Here, operations are indicated that are considered as unique resources in the company. Integrated utilization of technological capabilities, personality traits and professional dispositions as well as acquired knowledge and ability to apply it in practical implementation activities are indicated as a distinguishing mark by 27 of the surveyed respondents (62.8\% of the indications for 5 point score), substantially giving sense to the definition of dynamic competences (average score 4.53). The aspect of dynamic competences as a factor determining competitive advantage to the highest degree has been indicated by 24 respondents (average score 4.49; $55.8 \%$ of the indications for 5 point score). According to the adopted definition, it is collections of knowledge and skills that underlay the implementation dynamics. Here, significant is the distinguishing mark of competences that requires them to be anchored in the organizational culture as well as implanted into the organizational structure and action systems, which is emphasized by

Dynamic competences in the opinion of the machine sector experts - from management theory to practice 
M. Bratnicki (2000, p. 25). It determines the ability to immediately respond, which, through properly harmonized resources reconfiguration, implies the possibility of taking advantage of the opportunities appearing in the environment (average score 4.44; 23 (53.5\%) of the indications for 5 point score).

Tangible, capital, human and information resources as essential factors that determine execution of the assumed tasks are indicated by 25 respondents (average assessment $4.42 ; 58.1 \%$ of the indications for 5 point score). Dynamic competences are also characterized by attitudes and behaviors of performers of the tasks (average assessment 4.30; 41.9\% of the indications for 5 point score). According to 18 respondents they will cause acceptance of new technologies to the highest extent, which, in the perspective of having dynamic capabilities, with their appropriate reconfiguration, implies maintenance of the leading cost leader's position. Recommended is thus to have, and to have the ability to utilize, material resources in the form of machines, tools and equipment used for processing and manufacturing (average assessment 4.02; 13 (30.2\%) of the indications for 5 point score). Another characteristic states that dynamic competences is the ability to solve technological and management problems (average assessment 4.00; 15 (34.9\%) of the indications for 5 point score). Here, the need for assimilating knowledge and specified experience is emphasized. Knowledge and experience supported by personal dispositions and motivations of executive employees get the company closer to implementation of the adopted assumptions (average assessment 3.86; $11(25.6 \%)$ of the indications for 5 point score).

Characteristics of an entity made relative to efficient performance of a certain act, performing functions in the organization, the ability to focus on certain areas of tasks, characteristics of the entity that are at the core of effective action or behaviour at work as well as a visible characteristic in the form of knowledge, skills or behaviours, permitting successful functioning in a given function, are the distinguishing marks differently indicated by the respondents in terms of significance (tab. 1).

Table 1. Dynamic competences - distinguishing characteristics in the opinion of the respondents

\begin{tabular}{c|c}
\hline Dynamic competences - distinguishing characteristics & $\begin{array}{c}\text { Average } \\
\text { assessment }\end{array}$ \\
\hline $\begin{array}{l}\text { Visible characteristic in the form of material resources, knowledge, skills or } \\
\text { behaviours, permitting successful utilization of any emerging opportunities }\end{array}$ & 3.81
\end{tabular}


Knowledge, experience, capabilities and dispositions for team activities applied at the work post, specific skills required at work and organizational culture 3.77 adopted by the entity

Resources being in readiness for intensive development - through the implementation of appropriately designed and adjusted goals adopted by the organization

Knowledge, ability, experience and motivations to carry out evolutionary and revolutionary changes

Having resources implying the ability of the company to provoke and take advantage of opportunities

Knowledge in the field of technology, design, operation and construction of machines

Creativity of employees; thinking leading to original and appropriate solutions; ability to create something new

Ability to adapt to changes taking place within the enterprise and in its environment

Ability to learn fast, adapting the enterprise to changes simultaneously implementing different action options

Ability to dynamically adjust the goals of the organization to the conditions in which it has to operate

Source: authors' own study on the basis of research

The notion 'dynamic competences' involves many ambiguities which cause difficulties in defining and classifying the term. In particular, the problem is concerned with explicit definition of the term both by the authors representing management sciences and by management practitioners. Confusion has developed that sometimes leads to contradictory opinions, or even disputes, concerning what dynamic competences are indeed, and therefore - what methods to use to examine and then improve them.

In spite of many attempts to agree positions among management practitioners, there is no clear consent on the importance of this notion. Search for one, common or universal characteristic, if possible at all, would enrich neither knowledge nor practice of management, and, at the same time, could result in narrowing the research field. It is emphasized that the only proper way of practicing management sciences, at least in the present stage of their development, is 
multiplicity of ways of perception, interpretation and shapes of the examined part of the reality (Krzyżanowski 1992, p. 63).

In particular, specific confusion around the notion 'dynamic competences' is caused by the following factors:

- there are many distinguishing marks of the term 'competences',

- perception of the essence of material and intangible resources in terms of building competitive advantages is different,

- management sciences have the interdisciplinary nature, being affected by different research trends,

- transfer of practical experience without any clear selection of the characteristic determining factors is observed,

- in the definition miscellany of dynamic competences, a narrowed or developed effectiveness context can be noticed. They can be distinguished as the potential contributing to achieving specified (desired) results,

- competences is the ability to make something that is necessary.

In the context of the above, attempts madein the paper to establish terminological order are only of cognitive nature, enabling common areas, interrelations and research approaches to be captured. In addition, systematization of various perspectives of the same problem increases chances for a complex analysis and may be an inspiration for further research.

\section{Conclusions}

The main purpose of the presented work was an attempt to answer the question: how is the notion 'dynamic competences' understood by representatives of manufacturing companies operating in the Polish farm machines sector? As a result of the conducted research, it has been determined that dynamic competences are most often distinguished by tangible resources, including means of production, items of work and technology. Thanks to available engineering knowledge and the ability to translate it into practical solutions, and also based on dispositions of executive employees and their experience, attitudes, motives and behaviours - these resources allow the opportunities emerging in the environment to be taken advantage of. Dynamic competences with a bundle of resources implying a company's competitive advantage; utilization (implementation) of an independently created or provoked opportunity is reflected in the heterogeneous character of the product portfolio, which, in turn, gives the manufacturer access to new target markets (diversification) often contributing to reduced production costs (fig. 1). 


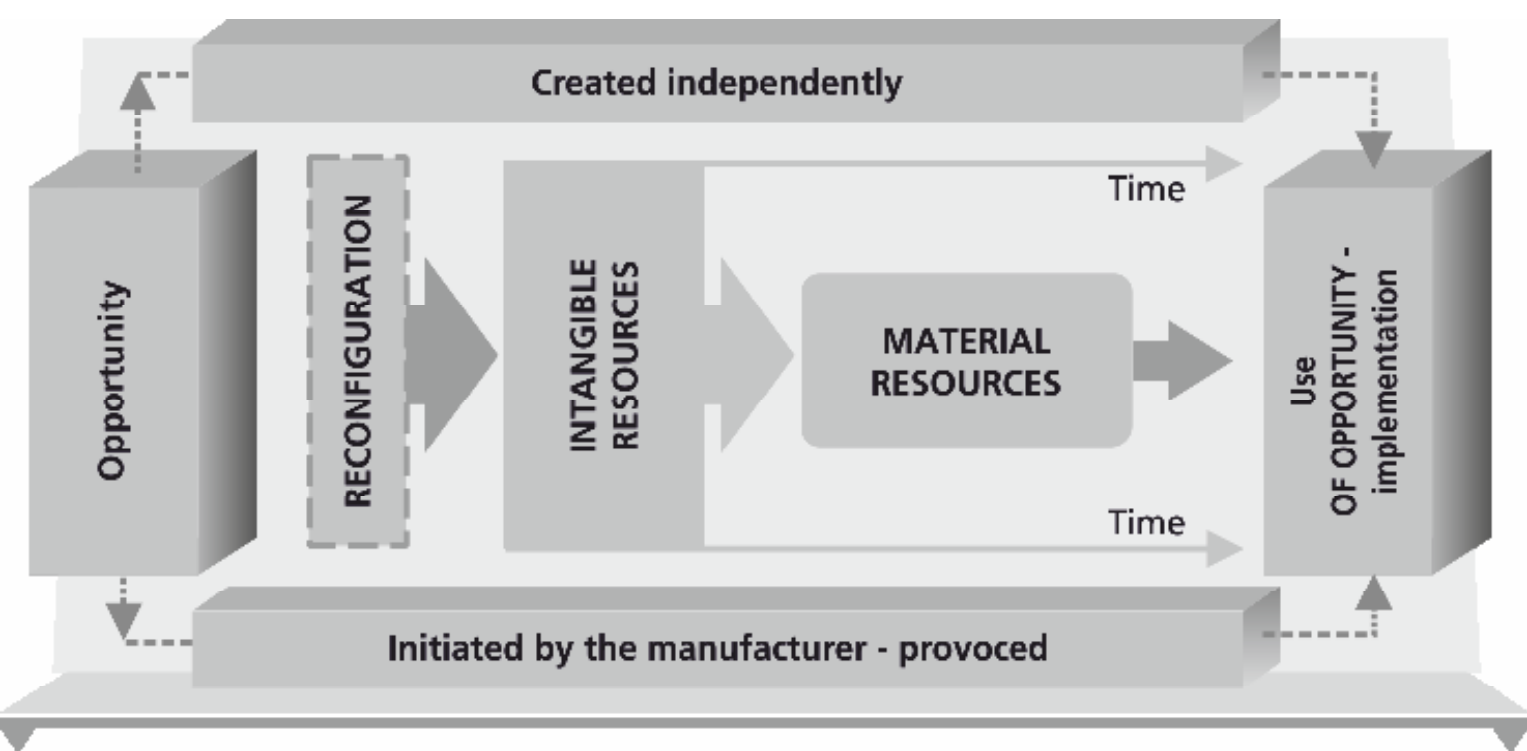

Figure 1. Dynamic competences as a bundle of resources - definition perspective

Source: own study on the basis of research

Specified in the prepared definition, the components create a certain system by mutual links. Using the terminology borrowed from the systems theory, it can be stated that dynamic competences are a coherent set where change of one element (e.g. purchase of a new machine) causes change in the others - not necessarily all - component parts; e.g. under the influence of a new technology, attitude to work is changed. Dynamic competences are a set of material and intangible resources which, with the present state of knowledge, cannot be precisely and completely foreseen and defined.

\section{Summary}

Dynamic competence in the opinion of the machinery sector experts - from theory to management practice

The main objective of this paper is an attempt to reply to the question: how is the concept of dynamic competence understood by representatives of the manufacturing companies operating in the Polish agricultural machinery sector? Within the theoretical and design measures, a method of reconstruction and interpretation of literature implying the discussion in a group of intentionally selected experts operating in the examined sector will be used; as a result of the creative discussion, the key designates of 
dynamic competence will be generated. At the empirical level, it was considered appropriate to determine the hierarchy of their importance. The task of deliberately selected respondents will be to make a choice as to which of the suggested dimensions of the dynamic competence best reflects the sense of this concept.

Keywords: dynamic competence, tangible resources, intangible resources, dynamic capabilities.

\section{Streszczenie}

Kompetencje dynamiczne $w$ opinii ekspertów sektora maszynowego - od teorii do praktyki zarządzania

Zasadniczym celem pracy jest próba odpowiedzi na pytanie: jak pojęcie kompetencji dynamicznych rozumiane jest przez przedstawicieli przedsiębiorstw produkcyjnych działających w polskim sektorze maszyn rolniczych? W warstwie teoretycznej i projektowej wykorzystana została metoda rekonstrukcji i interpretacji literatury implikująca dyskusję w grupie celowo dobranych ekspertów działających w badanym sektorze; $w$ wyniku twórczej dyskusji wygenerowane zostały kluczowe desygnaty kompetencji dynamicznych. Na płaszczyźnie empirycznej za zasadne uznano ustalenie hierarchii ich ważności. Zadaniem celowo dobranych respondentów było dokonanie wyboru, które $\mathrm{z}$ zasugerowanych wymiarów kompetencji dynamicznych najbardziej oddają sens tego pojęcia.

\section{Słowa}

kluczowe: kompetencje dynamiczne, zasoby materialne, zasoby niematerialne, zdolności dynamiczne.

JEL

Classification: E20, I12, E24

\section{References}

1. Bieniok H. (2016), Kompetencje i przedsiębiorczość osobista menedżera $w$ zarzadzaniu biznesem [Competences and personal entrepreneurship of business management manager], [in:] J. Rokita (ed.), Kompetencje - Modele biznesu Strategie [Competences - business models - Strategies], Górnośląska Wyższa Szkoła Handlowa im. Wojciecha Korfantego, Katowice, p. 94-108.

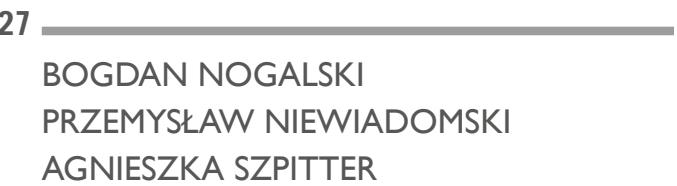


2. Bratnicki M. (2000), Kompetencje przedsiębiorstwa. Od określenia kompetencji do zbudowania strategii [Competencies of an enterprise. From determination of competencies to building a strategy], Agencja Wydawnicza Placet, Warsaw.

3. Cyfert S. (2012), Systemowy model organizacji: perspektywa procesów odnowy strategicznej [Organisation systemic model: the prospect of organisational renewal processes], [in:] G. Bełz, S. Cyfert (ed.), Strategie i mechanizmy odnowy przedsiębiorstw [Strategies and mechanisms for the renewal of enterprises], „Prace Naukowe Uniwersytetu Ekonomicznego we Wrocławiu”, Nr 276, Wydawnictwo Uniwersytetu Ekonomicznego we Wrocławiu, Wrocław.

4. Czakon W. (2017), Tworzenie teorii w naukach o zarzadzaniu [Creating theories in management sciences], [in:] A. Sopińska, P. Wachowiak (ed.), Wyzwania wspótczesnego zarządzania strategicznego [Challanges of the contemporary strategic management], Szkoła Główna Handlowa w Warszawie - Oficyna Wydawnicza, Warsaw, p. 143-159.

5. Eisenhardt K. M., Martin J. A. (2000), Dynamic Capabilities: What are They?, "Strategic Management Journal", vol. 21, p. 1105-1121.

6. Falencikowski t. (2013), Spójność modeli biznesu. Koncepcja i pomiar [The consistency of business models. Concept and measurement]., CeDeWu, Warsaw.

7. Guliński P., Studziński W. (2008), Zarządzanie przez szanse na przykładzie firmy "Wagony Świdnica SA"[Management through chances based on the example of "Wagony Świdnica SA company", [in:] A. Kaleta, K. Moszkowicz (ed.), Zarzadzanie strategiczne $w$ badaniach teoretycznych $i$ w praktyce [Strategies and mechanisms for the renewal of enterprises], "Prace Naukowe Uniwersytetu Ekonomicznego we Wrocławiu", Nr 20, Wydawnictwo Uniwersytetu Ekonomicznego we Wrocławiu, Wrocław.

8. Hambrick D. C. (2007), The field management's devotion to theory: Too much of a good thing? "Academy of Management Journal", Vol. 50, Issue 6, pp. 1346-1352.

9. Karpacz J. (2014), Zdolność technologiczna i innowacje produktów: Ujęcie teoretyczne $i$ wyniki badań empirycznych [Technological capability and product innovations: Theoretical approach and results of empirical research], [in:] T. Kraśnicka (ed.), Innowacyjność wspótczesnych organizacji. Kierunki i wyniki badań [Innovation of contemporary organizations.Directions and research results], „Studia Ekonomiczne”, no. 183, Katowice, p. 55-67.

10. Krupski R. (ed.) (2005), Zarządzanie przedsiębiorstwem w turbulentnym otoczeniu. Ku superelastycznejorganizacji, [Company management in a turbulent environment. Towards superflexible organisation]., Polskie Wydawnictwo Ekonomiczne, Warsaw.

11. Krzakiewicz K., Cyfert S. (2016(1)), Strategiczny potencjat organizacji uczacej sie $w$ aspekcie koncepcji dynamicznych zdolności [Strategic potential of the learning organization in the aspect of the concept of dynamic abilities], "Studia i Prace Kolegium Zarządzania i Finansów", Zeszyt Naukowy 149, Szkoła Główna Handlowa w Warszawie, p. 44-59.

\footnotetext{
Dynamic competences in the opinion of the machine sector experts - from management theory to practice
} 
12. Krzakiewicz K., Cyfert S. (2016(2)), Dylematy ksztattowania strategicznego w ujęciu teorii Firmy - na przykładzie zarzadzania strategicznego [Dilemmas of strategic shaping in terms of the theory of the Company - on the example of strategic management], [in:] G. Osbert-Pociecha,. S. Nowosielski (ed.), Meandry teorii i praktyki zarzadzania [Meanders of management theory and practice], Wydawnictwo Uniwersytetu Ekonomicznego we Wrocławiu, Wrocław, p. 83-94.

13. Krzakiewicz K., Cyfert S. (2016(3)), Strategiczny potencjat organizacji uczacej się $w$ aspekcie koncepcji dynamicznych zdolności [Strategic potential of the learning organization in the aspect of the concept of dynamic abilities], "Studia i Prace Kolegium Zarządzania i Finansów", Zeszyt Naukowy 149, Szkoła Główna Handlowa w Warszawie, p. 44-59.

14. Krzyżanowski L. (1992), Podstawy nauk organizacji $i$ zarzadzania [Fundamentals of organisation and management sciences], Państwowe Wydawnictwo Naukowe, Warsaw.

15. Niewiadomski P. (2016), Determinanty elastyczności funkcjonowania przedsiębiorstwa produkcyjnego sektora maszyn rolniczych [Determinants related to flexibility of functioning of a manufacturing company of the agricultural machinery sector], Wydawnictwo Politechniki Poznańskiej, Poznań.

16. Nogalski B., Klisz S. (2012), Koncepcje $i$ metody zarządzania zasobami leśnymi, [Concepts and forest management methods], Wydawnictwa Fachowe CEDEWU, Warsaw.

17. Nogalski B., Niewiadomski P. (2017), Elastyczność polskich wytwórców sektora maszyn rolniczych jako implikator dyskusji o modelu technicznych zdolności dynamicznych, [Flexibility of the Polish manufacturers of the agricultural sector as a discussion implicator on the model of technical dynamic capabilities], in print.

18. Nogalski B., Szpitter A. A. (2012), Kultura organizacyjna w zarzadzaniu organizacja wielokulturowa [Organizational culture in the management of multicultural organisation], [in:] B. Mikuła (ed.), Historia i perspektywy nauk o zarzadzaniu [History and perspectives of the management sciences], Fundacja Uniwersytetu Ekonomicznego, Kraków.

19. Nogalski B., Szpitter A. A., Niewiadomski P. (2017), Problematyka badań $w$ postępowaniach habilitacyjnych $w$ dyscyplinie nauki o zarzadzaniu w latach 2007-2016 [Research issues in habilitation proceedings in the management science discipline in 2007-2016], [in:] Cz. Zając (ed.), Nauki ekonomiczne $w$ XXI wieku - dylematy, wyzwania, perspektywy [Economic sciences in the 21st century - dilemmas, challenges, perspectives], Wydawnictwo Uniwersytetu Ekonomicznego we Wrocławiu, Wrocław, p. 225-240.

20. Nogalski B., Szpitter A. A. (2014), Kultura organizacyjna w zarzadzaniu organizacja wielokulturowa [Organizational culture in the management of multicultural organisation], [in:] I. Hejduk. A. Herman (ed.) Zarzadzanie dla przyszłości [Management for the future], Difin, Warsaw. 
21. Ortega M. J. R. (2010), Competitive Strategies and Firm Performance: Technological Capabilities' Moderating Roles, "Journal of Business Research", Vol. 63.

22. Quinn J. B., Hilmer F. G. (1996), Core Competencies and Strategic Outsourcing, [in:] J. B. Quinn, H. Mintzberg (eds.), The Strategy Process: Concepts, Contexts and Cases, Prentice-Hall International, London, p. 63-73.

23. Sajdak M. (2014), Zwinność przedsiębiorstwa jako koncepcja zarządzania między stabilnościa a chaosem [Business agility as a concept of management between stability and chaos], [in:] M. Romanowska, J. Cygler (ed.), Granice zarzadzania [Management boundaries], Szkoła Główna Handlowa w Warszawie Oficyna Wydawnicza, Warsaw.

24. Skalik J. (2012), Ewolucja metodycznego wspomagania procesu zarzadzania zmianami $w$ organizacjach [Evolution of methodical support of change management processes in organizations], [in:] Bełz G, Cyfert S. (eds.), Strategie $i$ mechanizmy odnowy przedsiębiorstw [Strategies and mechanisms of enterprise renewal], Wydawnictwo Uniwersytetu Ekonomicznego we Wrocławiu, Wrocław, „Prace Naukowe”, No. 276, p. 28-37.

25. Stankiewicz J., Łychmus P., Bortnowska H. (2011), Szanse upowszechniania programów etycznych wśród pracowników bankowych poprzez e-learning [Opportunities to disseminate ethical programs among banking employees through e-learning], [in:] G. Rosa, A. Smalec, L. Gracz, Marketing przysztości. Trendy. Strategie. Instrumenty [Marketing of the future. Trends. Strategies. Instruments. Marketing $w$ działalności podmiotów rynkowych [Marketing in the activity of market entities], ,Zeszyty Naukowe”, No. 662, „Ekonomiczne Problemy Usług" No. 74, Wydawnictwo Naukowe Uniwersytetu Szczecińskiego, Szczecin, p. 581-593.

26. Teece D. J. (2007), Explicating dynamic capabilities: the nature and microfoundations of (sustainable) enterprise performance, "Strategic Management Journal", Volume 28, Issue 13, p. 1267-1369.

27. Teece D. J. (2012), Dynamic Capabilities: Routines versus Entrepreneurial Action, "Journal of Management Studies", Vol. 49, Issue 8.

28. Teece D., Pisano G., Shuen A. (1997), Dynamic capabilities and strategic management, „Strategic Management Journal”, Vol. 18, No. 7, p. 1395-1401.

29. Thompson J. L., Richardson B. (1996), Strategic and Competitive Success: Towards a model of the Comprehensively Competent Organization, „Management Decision”, No. 2, p. 5-19.

30. Trocki M., Grucza B., Ogonek K. (2009), Zarzadzanie projektami [Project management], Polskie Wydawnictwo Ekonomiczne, Warsaw.

31. Trzcieliński S. (2011), Przedsiębiorstwo zwinne [Agile company], Wydawnictwo Politechniki Poznańskiej, Poznań. 